\title{
Improving the Effects of Salt Stress by $\beta$-carotene and Gallic Acid Using Increasing Antioxidant Activity and Regulating Ion Uptake in Lepidium Sativum L.
}

\author{
Marziyeh Babaei \\ Shahrekord University \\ Leila Shabani \\ Shahrekord University \\ shahla hashemi shahraki ( $\nabla$ shahlahashemi15@yahoo.com ) \\ University of Sistan and Baluchestan
}

\section{Original Article}

Keywords: Antioxidant, $\beta$-Carotene, Gallic Acid, Lepidium sativum, Sodium Chloride

Posted Date: December 29th, 2021

DOl: https://doi.org/10.21203/rs.3.rs-1172279/v1

License: (a) (1) This work is licensed under a Creative Commons Attribution 4.0 International License. Read Full License 


\section{Abstract}

Background: Plant growth, physiological and biochemical processes are severely affected by soil salinity. In the present study, toward investigating the interaction of antioxidants and salt stress in Lepidium sativum seedlings, two antioxidants ( $\beta$-carotene and gallic acid) were sprayed on the plants.

Results: The findings revealed that total dry and fresh weight were adversely affected by $25 \mathrm{mM} \mathrm{NaCl}$ salinity stress. Moreover, $\mathrm{K}^{+}$content decreased while $\mathrm{Na}^{+}$content increased significantly. The application of $\beta$-carotene and gallic acid significantly improved tolerance to salt stress by regulating ion uptake, reducing $\mathrm{H}_{2} \mathrm{O}_{2}$ and malondialdehyde (MDA) content, as well as increasing enzymatic antioxidant activity and phenolic, glutathione, and chlorophyll content.

Conclusions: Our findings are indicative of $\beta$-carotene and gallic acid in the induction of salt tolerance in economically important crops.

\section{Introduction}

A plant's secondary metabolites are not essential for the completion of the plant growth and development cycle, but they play an important role in regulating plant interactions and their adaptation to environmental factors, as well as in defense processes against biotic and abiotic stresses (Yang et al. 2018). In higher plants, a wide range of secondary metabolites is synthesized from primary metabolites such as carbohydrates, lipids, and amino acids at low concentrations. Environmental factors such as temperature, humidity, light intensity, water supply, minerals, and $\mathrm{CO}_{2}$ influence the production of secondary metabolites (Akula and Ravishankar 2011; Alvarado et al. 2019).

The main carotenoids in plants are lutein, lycopene, and $\beta$-carotene (Figure 1). $\beta$-carotene and other carotenoids are the most efficient natural ${ }^{1} \mathrm{O}_{2}$ quenchers (Siems and others 1999). The number of double bonds in their molecules are closely related to their quenching activity. $\beta$-carotene may be useful in quenching singlet oxygen and scavenging free radicals. There are several studies indicating that plants under environmental stress improve the adverse effects of stress by increasing $\beta$-carotene content. For example, Kim et al. (2012) suggested that increased levels of $\beta$ carotene in transgenic cultured cells of sweet potato cause stress tolerance to salt (Kim et al. 2012). Also, Kim et al. (2012) reported that in tomatoes, high salt concentrations increased antioxidant capacity and increased the carotene content by $35 \%$ (Kim et al. 2012). Long-term salt treatment in lettuce increases $\beta$-carotene and lutein levels by up to $80 \%$ and $37 \%$, respectively (Kim et al. 2008). Like $\beta$-carotene, gallic acid is an important plant antioxidant. Gallic acid is a component of phenolic compounds (Figure 1). Gallic acid is an effective compound in scavenging free radicals and inhibiting the lipid peroxidation process. It also improves the effects of various abiotic stresses such as chilling, heavy metals, and osmotic stress. Yildiztugay et al. (2017) reported that gallic acid in soybean led to resistance to cold stress through its ability to inhibit free radicals and improve water status and photosynthetic capacity (Yildiztugay et al. 2017). Treatment of gallic acid in tomato callus reduces the negative effect of excessive boroninduced damage by reducing boron uptake or preventing growth inhibition (Farghaly et al. 2021). However, very little research is available on the exogenous use of $\beta$-carotene and gallic acid in reducing the adverse effects of salinity stress on plants. The main purpose of this study was to investigate the effects of exogenous gallic acid and $\beta$ carotene on Lepidium sativum exposed to salt.

\section{Materials \& Methods}


Seeds of Lepidium sativum L. were collected from Shahrekord, Iran. To determine the threshold concentration of salt as well as the most appropriate concentration of phenolic compounds that have the best impact on growth $L$. sativum, preliminary experiments were performed. In the preliminary experiments, the effects of different concentrations of $\mathrm{NaCl}(0,25,50,100,150,200,250,300$ and $350 \mathrm{mM}), \beta$-carotene $(0,0.5,2.5 .5 \mathrm{mM})$ and gallic acid $(0,0.5,1,2.5,5,10,12.5,15,20 \mathrm{mM})$ were evaluated on seed germination and seedling growth for 5 days. Therefore, citing the findings of the preliminary experiments, a concentration of $25 \mathrm{mM} \mathrm{NaCl}$, a concentration of $0.5 \mathrm{mM} \beta$ carotene, and $5 \mathrm{mM}$ gallic acid were used for the main experiment. In the main experiment, ten surface-sterilized seeds were placed in the $90 \mathrm{~mm}$ petri dish containing $30 \mathrm{ml}$ of distilled water and incubated in a growth chamber (25 C, $50 \%$ humidity, light for $16 \mathrm{~h}$, and dark for $8 \mathrm{~h}$ ) for 5 days. 5-day-old seedlings were transferred to culture trays containing perlite and irrigated with Hoagland nutrient solution. The seedlings were grown in a greenhouse with a photoperiod of $16 / 8 \mathrm{~h}$ light / dark under $27^{\circ} \mathrm{C}$. Then, solutions of $\beta$-carotene $(0.5 \mathrm{mM})$ and gallic acid $(5 \mathrm{mM})$ were sprayed (foliar) on the seedlings for three consecutive days (three times a day). After antioxidant treatment, eightday-old seedlings were treated with the Hoagland solution containing $25 \mathrm{mM} \mathrm{NaCl}$. The experiment was carried out with a randomized complete design with 3 replicates using the following treatments:
1) Control
2) $\beta$-carotene 3)
3) Gallic acid 4) $\mathrm{NaCl}$
5) $\beta$-carotene $+\mathrm{NaCl}$
6) Gallic acid $+\mathrm{NaCl}$

After one week of treatment, the plants were harvested and their fresh and dry weights were measured and then stored at $-80^{\circ} \mathrm{C}$ for further analysis.

\section{Determination of total chlorophyll content}

The total chlorophyll content was determined spectrophotometrically using $0.1 \mathrm{~g}$ FW of leaf tissue ground with mortar and pestle in $10 \mathrm{ml}$ of acetone $80 \%(\mathrm{v} / \mathrm{v})$. After centrifugation and reading the absorbance values at 663,645 , and $470 \mathrm{~nm}$, the values in the following equations were used (Arnon 1949). The contents were expressed as mg total chlorophyll g ${ }^{-1} \mathrm{FW}$.

Eq. $\left(\right.$ A.1) Totalchlorophyll $(\mathrm{mg} \mid \mathrm{gFW})=\left((8.02 \times\right.$ A663) $+(20.2 \times A 645)) \times \frac{(\operatorname{volumeofacetone}(\mathrm{ml})}{\text { weightofsample }(\mathrm{mg}) \times 1000}$

\section{Determination of total phenolic content and DPPH radical scavenging activity}

Using the Singleton and Rossi (1965) methods, the total soluble phenolic compounds were estimated (Singleton and Rossi 1965). The frozen leaf tissue $(0.1 \mathrm{~g})$ was ground with $3 \mathrm{ml}$ of $80 \%$ methanol in a cooled mortar. The obtained extract was centrifuged at $15000 \mathrm{rpm}$ for 15 minutes. The supernatant was used to measure the amount of phenolic compounds. The absorbance of the reaction mixture consisting of $30 \mu \mathrm{l}$ of extract, $120 \mu \mathrm{l}$ of sodium carbonate $\left(\mathrm{Na}_{2} \mathrm{Co}_{3}\right)$, and $150 \mu \mathrm{l}$ of Folin-Ciocalteu reagent was read at $765 \mathrm{~nm}$ after exposure to darkness for $30 \mathrm{~min}$.

Utilizing the Kulisic et al. (2004) method, radical scavenging activity was estimated by a spectrophotometric method based on the reduction of a methanol solution of DPPH (Kulisic et al. 2004). An aliquot of $1 \mathrm{ml}$ of the plant extract was added to $1 \mathrm{ml}$ DPPH solution in a concentration of $100 \mu \mathrm{M}$ in methanol. The control sample was prepared without any extract. The resultant absorbance was measured at $517 \mathrm{~nm}$, after 30 min incubation in darkness at ambient temperature. Radical scavenging activity was calculated using the following equation.

$$
\text { Eq. (A.2)Inhibition(\%) }=\frac{\text { Acontrol }- \text { Asample }}{\text { Acontrol }} \times 100
$$




\section{Measurement of oxidative stress markers Determination of $\mathrm{H}_{2} \mathrm{O}_{2}$ and malondialdehyde (MDA) content}

$\mathrm{H}_{2} \mathrm{O}_{2}$ was measured spectrophotometrically $(\lambda=390 \mathrm{~nm})$ by a reaction with $1 \mathrm{M} \mathrm{KI}$ according to Alexieva et al. (2001). $0.1 \mathrm{~g}$ of frozen leaf tissue was ground in a cooled mortar with $1.5 \mathrm{ml}$ of TCA (trichloroacetic acid) $0.1 \%$ (Alexieva et al. 2001). The obtained extract was centrifuged at $15000 \mathrm{~g}$ for 4 minutes at $4^{\circ} \mathrm{C} .500 \mu \mathrm{l}$ of supernatant was added to $500 \mu \mathrm{l}$ of $10 \mathrm{mM}$ phosphate buffer and $1 \mathrm{~mL}$ of $1 \mathrm{M} \mathrm{KI}$ solution. The absorption rate was read by a spectrophotometer at $390 \mathrm{~nm}$. The malondialdehyde (MDA) content was detected by commercially available kits (KIA ZIST, Hamadan, Iran). The MDA content was expressed as nmol MDA/gFW.

Determination of Glutathione (GSH) Level, Catalase (CAT), Superoxide Dismutase (SOD) Guaiacol Peroxidases (GPX), Glutathione Reductase (GR) \& Ascorbate Peroxidase (APX) Enzymes Activities

Glutathione (GSH) level and glutathione reductase (GR) were detected by commercially available kits (KIA ZIST, Hamadan, Iran). The GSH levels and GR activity were measured according to the manufacturer's instructions. The absorption of both was measured using a spectrophotometer at $405 \mathrm{~nm}$.

The CAT, SOD and GPX, APX enzyme activities were determined by the following method. $0.1 \mathrm{~g}$ of each sample was homogenized in the extraction buffer (PBS) pH 7.8. The catalase activity was measured utilizing the method described by Aebi (1984) (Aebi 1984). The activity was estimated via monitoring the decrease in absorbance due to $\mathrm{H}_{2} \mathrm{O}_{2}$ decomposition [extinction coefficient $\left(\varepsilon=39 \mu \mathrm{mol}^{-1} \mathrm{~cm}^{-1}\right)$ ] at $240 \mathrm{~nm}$. The reaction mixture contained $50 \mu \mathrm{l}$ plant extract, $50 \mathrm{mM}$ phosphate buffer ( $\mathrm{pH}$ 7.0), and $10 \mathrm{mM} \mathrm{H}_{2} \mathrm{O}_{2}$. The SOD activity was measured spectrophotometrically, as described by Beyer and Fridovich (1987) (Beyer and Fridovich 1987), and assayed by monitoring the inhibition of photochemical reduction of nitro blue tetrazolium (NBT). For the amount of enzyme which causes $50 \%$ inhibition of the NBT photo-reduction rate in 1 minute at $560 \mathrm{~nm}$, a unit of SOD activity was defined. The specific activity of SOD was expressed as unit/mg FW. For GPX activity estimation (Lin and Kao 1999), the reaction was initiated by adding the plant extract $(50 \mu \mathrm{l})$ to a reaction mix comprising $50 \mathrm{mM}$ phosphate buffer, 19 $\mathrm{mM} \mathrm{H}_{2} \mathrm{O}_{2}$, and $9 \mathrm{mM}$ guaiacol. The absorbance was recorded at $470 \mathrm{~nm}$ for the amount of enzyme which forms 1 $\mu \mathrm{M}$ tetraguaiacol per minute at $470 \mathrm{~nm}$. According to the Nakano and Asada (1987) method for the measurement of APX activity, $50 \mu$ l plant extract, $50 \mathrm{mM}$ phosphate buffer containing $50 \mathrm{mM}$ phosphate buffer comprising $0.5 \mathrm{mM}$ ascorbic acid and $0.25 \mathrm{M} \mathrm{H}_{2} \mathrm{O}_{2}$ were utilized (Nakano and Asada 1987). Using a decrease in adsorption at $290 \mathrm{~nm}$, hydrogen peroxide-dependent oxidation of ascorbate was followed.

\section{Determination of $\mathrm{Na}^{+} \& \mathrm{~K}^{+}$Concentration}

The ash sample of shoots and roots were acid digested and filtered to determine $\mathrm{Na}^{+}$and $\mathrm{K}^{+}$concentration by a flame photometer (Corning, UK). $\mathrm{Na}^{+}$and $\mathrm{K}^{+}$content were recorded in $\mathrm{mg} / \mathrm{g} \mathrm{DW}$.

\section{Statistical Analysis}

All experiments were performed with three replications. All data were expressed as means \pm SE (Standard error). Oneway ANOVA was performed using SPSS ver. 17.0 software.

\section{Results}

Effects of $\beta$ - Carotene \& Gallic Acid Pre-Treatment on Seedlings Total Fresh Weight Under Salt Stress 
According to the findings of preliminary experiments to determine the concentration of sodium chloride, $\beta$-carotene, and gallic acid: 1 - for salinity treatment, $25 \mathrm{mM}$ sodium chloride caused a minimal reduction in seedling growth indices of L. sativum seedlings (Data not shown, Figure Suppl number 1-5). 2- Concentration of 0.5 mM $\beta$-carotene caused a maximum significant increase in growth indices of L. sativum seedlings (Data not shown, Figure Suppl number 6-9). 3- $5 \mathrm{mM}$ gallic acid concentration caused the maximum significant increase in seedling growth indices of L. sativum (Data not shown, Figure Suppl number 10-13). Therefore, $0.5 \mathrm{mM} \beta$-carotene and $5 \mathrm{mM}$ gallic acid were used to investigate the reduction of the effects of $25 \mathrm{mM}$ sodium chloride in L. sativum seedlings.

Compared to sodium chloride treatment, according to Figure $2 \mathrm{~A}, \beta$-carotene and gallic acid pretreatment increased the total fresh weight by $44 \%$ and $40 \%$, respectively. Salinity stress resulted in a $28 \%$ reduction in total fresh weight compared to control. The total fresh weight of seedlings treated with $\beta$-carotene + sodium chloride increased by $37 \%$ compared to seedlings treated with sodium chloride.

Figure 1B showed that $\beta$-carotene alone did not significantly change the total dry weight compared to gallic acid alone, but both led to an increase in total dry weight compared to control. Sodium chloride treatment resulted in a $22 \%$ reduction in total dry weight compared to the control. $\beta$-carotene + sodium chloride treatment resulted in a $48 \%$ increase in total dry weight compared to sodium chloride. Total dry weight under gallic acid + sodium chloride treatment increased by $27 \%$ compared to sodium chloride. Comparison of mean data showed that the highest total dry weight was observed in seedlings treated with $\beta$-carotene + sodium chloride and $\beta$-carotene alone, and the lowest root fresh weight was observed in seedlings treated with sodium chloride.

\section{Effects of $\boldsymbol{\beta}$ - Carotene \& Gallic Acid Pre-Treatment on Total Chlorophyll Content Under Salt Stress}

Salinity treatment had a negative effect on total chlorophyll content, while pretreatment of $\beta$-carotene and gallic acid increased the content of total chlorophyll compared to the control. An increase in the total chlorophyll content of $35 \%$ and $44 \%$ was observed in $\beta$-carotene $+\mathrm{NaCl}$ and gallic acid $+\mathrm{NaCl}$ treatments in comparison to the $\mathrm{NaCl}$ treatment, respectively (Figures 3 ).

\section{Effects of $\beta$ - Carotene \& Gallic Acid Pre-Treatment on $\mathrm{H}_{2} \mathrm{O}_{2}$ \& Malondialdehyde (MDA) Content Under Salt Stress}

The $\mathrm{H}_{2} \mathrm{O}_{2}$ content reported in figure 4A, the results showed that the $\mathrm{H}_{2} \mathrm{O}_{2}$ content under $\beta$-carotene and gallic acid pre-treatment decreased by $13 \%$ and $17 \%$, respectively, compared to the control. Sodium chloride treatment increased $\mathrm{H}_{2} \mathrm{O}_{2}$ by $63 \%$ compared to the control. $\beta$-carotene + sodium chloride and gallic acid + sodium chloride treatments reduced $\mathrm{H}_{2} \mathrm{O}_{2}$ by $33 \%$ and $37 \%$ compared to sodium chloride, respectively. As shown in figure $3 \mathrm{~B}$, the amount of MDA in treatment with $\beta$-carotene, gallic acid decreased by $6 \%$ and $5 \%$ compared to the control. Sodium chloride treatment showed a $99 \%$ increase in MDA compared to the control. $\beta$-carotene + sodium chloride and gallic acid + sodium chloride treatments reduced MDA content by $19 \%$ and $22 \%$, respectively, compared to sodium chloride.

\section{Effects of $\boldsymbol{\beta}$ - Carotene \& Gallic Acid Pre-Treatment on Phenolic, Glutathione Content \& DPPH Radical Scavenging Activity Under Salt Stress}

The findings of figure $5 \mathrm{~A}$ revealed that the content of phenolic compounds in $\beta$-carotene, gallic acid, and sodium chloride treatments increased by $15 \%, 19 \%$, and $11 \%$, respectively, compared to the control. $\beta$-carotene + sodium chloride and gallic acid + sodium chloride treatments increased phenolic compounds by $28 \%$ and $15 \%$, respectively, compared to sodium chloride. 
The results of figure 5B showed that the antioxidant activity of the plant under the treatments of $\beta$-carotene, gallic acid, and sodium chloride increased by $44 \%, 46 \%$, and $38 \%$, respectively, compared to the control. $\beta$-carotene + sodium chloride and gallic acid+sodium chloride treatments increased the plant's antioxidant activity by $4 \%$ and $6 \%$, respectively, compared to sodium chloride.

The findings of figure $5 \mathrm{C}$ demonstrated that the content of glutathione in $\beta$-carotene and gallic acid pre-treatment increased by $56 \%$ and $37 \%$, respectively, compared to the control. In sodium chloride treatment, a 3.84 -fold increase in the amount of glutathione was observed compared to the control. The amount of glutathione under $\beta$-carotene + sodium chloride and gallic acid + sodium chloride treatments decreased by $38 \%$ and $52 \%$, respectively, compared to sodium chloride.

\section{Effects of $\boldsymbol{\beta}$ - Carotene \& Gallic Acid Pre-Treatment on Antioxidant Enzymes Under Salt Stress}

Consistent with the findings, CAT, GPX, APX, SOD, and GR enzymes activities increased in the salinity-treated plants compared with the control. $\beta$-carotene and gallic acid pretreatments alone significantly increased the activities of CAT, GPX, APX, SOD, and GR enzymes compared to the control. A relatively larger increase in the activities of CAT, SOD, GR was observed in gallic acid treatment as compared to $\beta$-carotene. $\beta$-carotene + sodium chloride and gallic acid + sodium chloride treatments significantly increased the activities of CAT, GPX, APX, SOD, and GR enzymes compared to sodium chloride; however, the increase in the activities of SOD, GPX was more in gallic acid treatment than the $\beta$-carotene treatment under salinity stress. While the use of gallic acid and $\beta$-carotene in the activities of GPX and CAT was not significantly different under salinity conditions compared to each other (Figure 6A, B, C, D).

\section{Effects of $\beta$ - Carotene \& Gallic Acid Pre-Treatment on lons Analysis Under Salt Stress}

Salinity and $\beta$-carotene, gallic acid treatments showed a significant interaction on $\mathrm{Na}^{+}, \mathrm{K}^{+}$contents, $\mathrm{K}^{+} / \mathrm{Na}^{+}$ratio of shoot and root. Salinity stress reduced the $\mathrm{K}^{+}$content, $\mathrm{K}^{+} / \mathrm{Na}^{+}$ratio but increased $\mathrm{Na}^{+}$accumulation of roots and shoots compared to the control. Application of $\beta$-carotene alone and gallic acid alone significantly increased $\mathrm{K}^{+}$ contents, $\mathrm{K}^{+} / \mathrm{Na}^{+}$ratio of shoot and root but decreased $\mathrm{Na}^{+}$content. In shoot and root, $\beta$-carotene showed more effect on $\mathrm{Na}^{+}$reduction and $\mathrm{K}^{+}$content, $\mathrm{K}^{+} / \mathrm{Na}^{+}$ratio improvement compared with gallic acid. Treatment of $\beta$ carotene, gallic acid under salinity stress improved $\mathrm{K}^{+}$content and $\mathrm{K}^{+} / \mathrm{Na}^{+}$ratio of roots and shoots to stress conditions and reduced $\mathrm{Na}^{+}$uptake, indicating the positive effect of this pretreatment on increasing $\mathrm{K}^{+}$ions and decreasing $\mathrm{Na}^{+}$(Figure 7A, B, C, D, E, F).

\section{Discussion}

The present study was conducted to investigate the effects of $\beta$-carotene and gallic acid on salt stress mitigation in L. sativum. $\beta$-carotene and gallic acid played an important role in improving crop growth under salt stress in terms of increasing biomass production in L. sativum. Compared to control, pretreatment of $\beta$-carotene and gallic acid improves the total fresh weight and dry weight in two conditions without stress and $\mathrm{NaCl}$ stress. The findings demonstrated that increasing growth parameters under foliar-applied $\beta$-carotene was more effective than gallic acid under salinity stress, while in non-stress conditions, both antioxidants had a similar effect. Similarly, Dawood et al. (2019) reported that $\beta$-carotene priming significantly increased fresh weight and shoot height under drought stress in sunflower plants (Dawood et al. 2019). Enhancing growth parameters utilizing $\beta$-carotene and gallic acid under salt stress is associated with the decline of $\mathrm{Na}^{+}$uptake. Decreased $\mathrm{Na}^{+}$uptake leads to a high ratio of $\mathrm{K}^{+} / \mathrm{Na}^{+}$. A wellknown strategy to counteract $\mathrm{Na}^{+}$is to increase $\mathrm{K}^{+}$uptake. A suitable $\mathrm{K}^{+} / \mathrm{Na}^{+}$ratio is important for photosynthesis, 
protein synthesis, activation of multiple enzymes, stomatal function, and adjustment of cell osmoregulation (Zheng et al. 2008). Wakeel et al. (2011) stated that $\mathrm{Na}^{+}$toxicity affects the reduction of $\mathrm{K}^{+} / \mathrm{Na}^{+}$ratio, and consequently, $\mathrm{K}^{+}$ displacement by $\mathrm{Na}^{+}$in plant cells affects plasma membrane (PM) activity $\mathrm{H}^{+}$-ATPase (Wakeel et al. 2011). According to our findings, Saleh et al. (2015) reported that coumarin treatment significantly improved the $\mathrm{K}^{+} / \mathrm{Na}^{+}$ ratio in wheat seedlings under stress and non-stress conditions (Saleh et al. 2015).

Salinity stress induced a decrease in total chlorophyll content while $\beta$-carotene and gallic acid successfully ameliorated chlorophyll content in salinity stress. Similar to our findings, exogenously applied caffeic acid alleviated the adverse effects of salinity stress in soybean and improved chlorophyll content (Klein et al. 2015). Wu et al. (2015) suggested that increasing $\beta$-carotene could protect the photosynthetic abilities of transgenic tobacco plants under salinity stress (Wu et al. 2015). An appropriate indicator of the level of abiotic tolerance in plants is the chlorophyll content. Increased activity of chlorophyll degrading enzymes plus inhibition of chlorophyll biosynthesis following increased ethylene production can both be considered as reasons for the decrease in chlorophyll content in plants under salinity stress. The first defensive goal in salinity stress is to protect chlorophyll content. An increase in chlorophyll content in plants treated with $\beta$-carotene and gallic acid may be due to the effective removal of ROS by $\beta$ carotene and gallic acid, as well as increasing the activity of antioxidant enzymes. However, Wu et al. (2015) suggested that the antioxidant effect of $\beta$-carotene was associated with zeaxanthin biosynthesis (Wu et al. 2015). The biochemical derivative of $\beta$-carotene is zeaxanthin, produced by the activity of the $\beta$-carotene hydroxylase $(\mathrm{BCH})$ enzyme, via adding the hydroxyl group to each of the $\beta$-carotene rings (Zhu et al. 2008). An important component of the xanthophyll cycle is zeaxanthin, playing a key role in reactive oxygen species (ROS) scavenging and nonphotochemical quenching. In addition to its antioxidant role, $\beta$-carotene is able to bind to photosystems I (PSI) and II (PSII) in the subunits of the reaction center and cooperate with lutein and other xanthophylls in absorbing excess light energy used to transmit photosynthetic electrons (Cazzaniga et al. 2016).

The content of phenolic compounds under salinity stress in the plant increased compared to the control. Also, treatment of $\beta$-carotene and gallic acid under non-stress and salinity stress conditions increased the content of phenolic compounds. In addition, according to the present study, phenolic compounds in cucumbers under salt stress increased (Hýsková et al. 2017), and the amount of this compound in the treatment of rice with rutin and gallic acid was about 1.4 and 1.31 times higher than the control seedlings (Singh et al. 2017), respectively. Phenolic compounds act as radical scavengers by donating electrons or hydrogen atoms. There is a balance between the production and quenching of ROS under natural conditions. While under stress conditions such as salinity, the production of ROS is more than quenching, leading to oxidative stress. ROS induces membrane lipid peroxidation, reducing membrane fluidity and selectivity. Lipid peroxidation causes the production of malondialdehyde (MDA), considered a sign of oxidative damage (Juknys et al. 2012). To counteract the harmful effects of ROS, plants have an enzymatic antioxidant system including superoxide dismutase (SOD), catalyzing the conversion of $\mathrm{O}_{\cdot 2}{ }^{-}$to $\mathrm{H}_{2} \mathrm{O}_{2}$, which in turn is decomposed by the combined activities of catalase (CAT), guaiacol peroxidases (GPX) and ascorbate-glutathione cycle enzymes (Kubiś, 2008). Salinity stress in L. sativum enhanced the emergence of $\mathrm{H}_{2} \mathrm{O}_{2}$, while antioxidant treatment, especially gallic acid, reduced $\mathrm{H}_{2} \mathrm{O}_{2}$ content. $\mathrm{H}_{2} \mathrm{O}_{2}$ might be detoxified by CAT, GPX, APX, and GR activities and the ascorbate-glutathione cycle. $\mathrm{H}_{2} \mathrm{O}_{2}$ is relatively stable and not very reactive. $\mathrm{H}_{2} \mathrm{O}_{2}$ is electrically neutral ROS but is very dangerous because it can cross cell membranes and reach cellular parts far from the site of its formation. Ozfidan-Konakci et al. (2019) reported that cold stress significantly increased $\mathrm{H}_{2} \mathrm{O}_{2}$ content in soybean roots (Ozfidan-Konakci et al. 2019). But gallic acid has helped detoxify $\mathrm{H}_{2} \mathrm{O}_{2}$ by increasing the activity of CAT and GPX enzymes. Singh et al. (2017) also showed that the $\mathrm{H}_{2} \mathrm{O}_{2}$ content in plants treated with gallic acid decreased, whereby the control plants had the highest amount of $\mathrm{H}_{2} \mathrm{O}_{2}$. APX and GR are the glutathione ascorbate 
cycle enzymes (Singh et al. 2017). APX is considered the main $\mathrm{H}_{2} \mathrm{O}_{2}$-removing enzyme in plant cells, while GR plays a key role in maintaining glutathione depletion during stress. According to the results of the present study, pretreatment of $\beta$-carotene and gallic acid increased the activity of these enzymes in salinity stress. In addition to enzymatic antioxidants, plants also contain non-enzymatic antioxidants such as ascorbic acid, total phenols, proline, tocopherols, and glutathione.

Glutathione (GSH), Y-I-glutamyl-I-cysteinyl-glycine, is a free radical scavenger as well as an important antioxidant (Zechmann 2014). The important role of glutathione in regulating and controlling intracellular oxidation balance has been attributed to the thiol group. Oxidation and reduction of the thiol group lead to the formation of glutathione disulfide (GSSG) and reduced glutathione (GSH), respectively. GSSG is reduced to GSH by GR (Zechmann 2014). In this study, salinity stress significantly increased glutathione content. The use of $\beta$-carotene, gallic acid, $\beta$-carotene $+\mathrm{NaCl}$, gallic acid $+\mathrm{NaCl}$ also increased the glutathione content. Increased glutathione content under salinity and gallic acid and $\beta$-carotene may be related to increased GR activity. Enhancing GSH content and GR activity under salinity can be a viable mechanism to maintain the desired antioxidant state. Contrary to our findings, salinity stress decreased glutathione content in wheat, while $\beta$-carotene treatment increased glutathione content.

The effect of DPPH-radical scavenging is a measure of non-enzymatic antioxidant activity (Gülçin et al. 2007). To determine the disappearance of free radicals using a spectrophotometer, 1,1-diphenyl-2-picrylhydrazyl radical (DPPH.) is the most common and reliable method. While utilizing this method, the purple DPPH radical is reduced by antioxidants to the corresponding yellow DPPH-H, causing a decrease in absorbance at $515 \mathrm{~nm}$. High antioxidant activity indicates an increase in stress tolerance (Sairam et al. 2000). In this research, $\mathrm{NaCl}$ treatment significantly reduced antioxidant activity but was improved in salinity stress by $\beta$-carotene and gallic acid. This is consistent with Egedigwe and Udengwu (2021) findings, who reported increased DPPH-radical scavenging in Amaranthus Hybridus under $\beta$-carotene treatment (Egedigwe and Udengwu 2021). Similarly, Kahveci et al. (2021) stated that $\beta$-carotene priming resulted in increased phenolic compounds and DPPH-radical scavenging in Ocimum basilicum under salinity (Kahveci et al. 2021).

\section{Conclusion}

This study revealed that salinity stress had toxic effects on Lepidium sativum, confirmed by decreasing growth and chlorophyll content and increasing MDA and $\mathrm{H}_{2} \mathrm{O}_{2}$ content. $\beta$-carotene and gallic acid treatment can improve the tolerance of Lepidium sativum under salinity stress by increasing the growth and content of chlorophyll, glutathione, phenolics, antioxidant activity, plus regulating ion uptake (Fig. 8). The authors delineate that the process of mitigation of salinity stress by $\beta$-carotene and gallic acid could be similar, but the role of increasing non-enzymatic antioxidant activity and regulating ion uptake in $\beta$-carotene treatment was more significant than that of gallic acid. Furthermore, the increase in antioxidant enzymes (especially SOD and GR) activity by gallic acid treatment was more significant than $\beta$-carotene treatment.

\section{Abbreviations}

MDA, malondialdehyde; GSH, glutathione; CAT, catalase; SOD, superoxide dismutase; GPX, guaiacol peroxidases; GR, glutathione reductase; APX, ascorbate peroxidase.

\section{Declarations}

\section{Acknowledgements}


The authors thank Shahrekord University for providing the laboratory equipment.

\section{Funding}

This research received no specific grant.

\section{Ethics approval and consent to participate}

Not applicable.

\section{Consent for publication}

Not applicable.

\section{Competing Interests}

The authors declare that they have no known competing financial interests or personal relationships that could have appeared to influence the work reported in this paper.

\section{References}

1. Aebi H (1984) [13] Catalase in vitro. Meth Enzymol 105:121-126. https://doi.org/10.1016/S00766879(84)05016-3

2. Akula R, Ravishankar GA (2011) Influence of abiotic stress signals on secondary metabolites in plants. Plant signal Behav 6(11):1720-1731. https://doi.org/10.4161/psb.6.11.17613

3. Alexieva V, Sergiev I, Mapelli S, Karanov E (2001) The effect of drought and ultraviolet radiation on growth and stress markers in pea and wheat. Plant Cell Environment 24(12):1337-1344. https://doi.org/10.1046/j.13653040.2001.00778.x

4. Alvarado AM, Aguirre-Becerra H, Vázquez-Hernández MC, Magaña-Lopez E, Parola-Contreras I, Caicedo-Lopez LH, Contreras-Medina LM, Garcia-Trejo JF, Guevara-Gonzalez RG, Feregrino-Perez AA (2019) Influence of elicitors and eustressors on the production of plant secondary metabolites. In: Akhtar M, Swamy M, Sinniah U (eds) Natural Bio-active Compounds. Springer, Singapore.

5. Arnon D (1949) Determination of chlorophyll concentration in leaf tissues of plants. Plant Physiol 24(1).

6. Beyer Jr WF, Fridovich I (1987) Assaying for superoxide dismutase activity: some large consequences of minor changes in conditions. Anal Biochem 161(2):559-566. https://doi.org/10.1016/0003-2697(87)90489-1

7. Cazzaniga S, Bressan M, Carbonera D, Agostini A, Dall'Osto L (2016) Differential roles of carotenes and xanthophylls in photosystem I photoprotection. Biochemistry 55(26):3636-3649.

8. https://doi.org/10.1021/acs.biochem.6b00425

9. Dawood MG, El-Awadi ME-S, Sadak MS, El-Lethy SR (2019) Comparison Between the Physiological Role of Carrot Root Extract and $\beta$-carotene in Inducing Helianthus annuus L. Drought Tolerance. Asian J Biol Sci 12(2):231- 241. https://doi.org/10.3923/ajbs.2019.231.241.

10. Egedigwe UO, Udengwu OS (2021) Mitigating Effects of Beta-Carotene on Hydroponic Growth and Productivity of Amaranthus Hybridus L. under Aluminium Toxicity Induced Stress. Research Square. 1-31. https://doi.org/10.21203/rs.3.rs-645347/v1

11. Farghaly FA, Salam HK, Hamada AM, Radi AA (2021) The role of benzoic acid, gallic acid and salicylic acid in protecting tomato callus cells from excessive boron stress. Sci Hortic 278:109867.

https://doi.org/10.1016/j.scienta.2020.109867 
12. Gülçin İ, Elmastaş M, Aboul-Enein HY (2007) Determination of antioxidant and radical scavenging activity of Basil (Ocimum basilicum L. Family Lamiaceae) assayed by different methodologies. Phytother Res 21(4):354361. https://doi.org/10.1002/ptr.2069

13. Hýsková V, Plisková V, Červený V, Ryšlavá H (2017) NADP-dependent enzymes are involved in response to salt and hypoosmotic stress in cucumber plants. Gen Physiol Biophys 36:247-258.

14. https://doi.org/10.4149/gpb_2016053

15. Juknys R, Vitkauskaitė G, Račaitè M, Venclovienè J (2012) The impacts of heavy metals on oxidative stress and growth of spring barley. Cent Eur J Biol 7(2):299-306.

16. https://doi.org/10.2478/s11535-012-0012-9

17. Kahveci H, Bilginer N, Diraz-Yildirim E, Kulak M, Yazar E, Kocacinar F, Karaman S (2021) Priming with salicylic acid, $\beta$-carotene and tryptophan modulates growth, phenolics and essential oil components of Ocimum basilicum L. grown under salinity. Sci Hortic 281:109964.

18. https://doi.org/10.1016/j.scienta.2021.109964

19. Kim H-J, Fonseca JM, Choi J-H, Kubota C, Kwon DY (2008) Salt in irrigation water affects the nutritional and visual properties of romaine lettuce (Lactuca sativa L.). J Agric Food Chem 56(10):3772-3776. https://doi.org/10.1021/jf0733719

20. Kim SH, Ahn YO, Ahn M-J, Lee H-S, Kwak S-S (2012) Down-regulation of $\beta$-carotene hydroxylase increases $\beta$ carotene and total carotenoids enhancing salt stress tolerance in transgenic cultured cells of sweetpotato. Phytochemistry 74:69-78. https://doi.org/10.1016/j.phytochem.2011.11.003

21. Klein A, Keyster M, Ludidi N (2015) Response of soybean nodules to exogenously applied caffeic acid during NaCl-induced salinity. S Afr J Bot 96:13-18. https://doi.org/10.1016/j.sajb.2014.10.016

22. Kubiś J (2008) Exogenous spermidine differentially alters activities of some scavenging system enzymes, $\mathrm{H}_{2} \mathrm{O}_{2}$ and superoxide radical levels in water-stressed cucumber leaves. J Plant Physiol 165(4):397-406. https://doi.org/10.1016/j.jplph.2007.02.005

23. Kulisic T, Radonic A, Katalinic V, Milos M (2004) Use of different methods for testing antioxidative activity of oregano essential oil. Food Chem 85(4):633-640. https://doi.org/10.1016/j.foodchem.2003.07.024

24. Lin CC, $\mathrm{Kao} \mathrm{CH}(1999) \mathrm{NaCl}$ induced changes in ionically bound peroxidase activity in roots of rice seedlings. Plant Soil 216(1):147-153. https://doi.org/10.1023/A:1004714506156

25. Nakano Y, Asada K (1987) Purification of ascorbate peroxidase in spinach chloroplasts; its inactivation in ascorbate-depleted medium and reactivation by monodehydroascorbate radical. Plant cell physiol 28(1):131140. https://doi.org/10.1093/oxfordjournals.pcp.a077268

26. Ozfidan-Konakci C, Yildiztugay E, Yildiztugay A, Kucukoduk M (2019) Cold stress in soybean (Glycine max L.) roots: exogenous gallic acid promotes water status and increases antioxidant activities. Bot Serb 43(1):59-71. https://doi.org/10.2298/BOTSERB19010590

27. Sairam RK, Srivastava GC, Saxena DC (2000) Increased Antioxidant Activity under Elevated Temperatures: A Mechanism of Heat Stress Tolerance in Wheat Genotypes. Biol Plant 43(2):245-251. https://doi.org/10.1023/A:1002756311146

28. Saleh AM, Madany M (2015) Coumarin pretreatment alleviates salinity stress in wheat seedlings. Plant Physiol Biochem 88:27-35. https://doi.org/10.1016/j.plaphy.2015.01.005

29. Siems WG, Sommerburg O, Van Kuijk FJ (1999) Lycopene and $\beta$-carotene decompose more rapidly than lutein and zeaxanthin upon exposure to various pro-oxidants in vitro. Biofactors 10(2-3):105-113. 
https://doi.org/10.1002/biof.5520100204

30. Singh A, Gupta R, Pandey R (2017) Exogenous application of rutin and gallic acid regulate antioxidants and alleviate reactive oxygen generation in Oryza sativa L. Physiol Mol Biol Plants 23(2):301.

https://doi.org/10.1007/s12298-017-0430-2

31. Singleton VL, Rossi JA (1965) Colorimetry of total phenolics with phosphomolybdic-phosphotungstic acid reagents. Am J Enol Vitic 16(3):144-158.

32. Wakeel A, Farooq M, Qadir M, Schubert S (2011) Potassium substitution by sodium in plants. Crit Rev Plant Sci 30(4):401-413. https://doi.org/10.1080/07352689.2011.587728

33. Wu J, Ji J, Wang G, Wu G, Diao J, Li Z, Chen X, Chen Y, Luo L (2015) Ectopic expression of the Lycium barbarum $\beta$-carotene hydroxylase gene (chyb) enhances drought and salt stress resistance by increasing xanthophyll cycle pool in tobacco. Plant Cell Tissue Organ Cult 121(3):559-569. https://doi.org/10.1007/s11240-015-0725-3

34. Yang L, Wen K-S, Ruan X, Zhao Y-X, Wei F, Wang Q (2018) Response of plant secondary metabolites to environmental factors. Molecules 23(4):762. https://doi.org/10.3390/molecules23040762

35. Yildiztugay E, Ozfidan-Konakci C, Kucukoduk M (2017) Improvement of cold stress resistance via free radical scavenging ability and promoted water status and photosynthetic capacity of gallic acid in soybean leaves. J Soil Sci Plant Nutr 17(2):366-384. http://dx.doi.org/10.4067/S0718-95162017005000027

36. Zechmann B (2014) Compartment-specific importance of glutathione during abiotic and biotic stress. Front Plant Sci 5(566). https://doi.org/10.3389/fpls.2014.00566

37. Zheng Y, Jia A, Ning T, Xu J, Li Z, Jiang G (2008) Potassium nitrate application alleviates sodium chloride stress in winter wheat cultivars differing in salt tolerance. J Plant Physiol 165(14):1455-1465.

https://doi.org/10.1016/j.jplph.2008.01.001

38. Zhu C, Naqvi S, Breitenbach J, Sandmann G, Christou P, Capell T (2008) Combinatorial genetic transformation generates a library of metabolic phenotypes for the carotenoid pathway in maize. Proc Nati Acad Sci 105(47):18232-18237. https://doi.org/10.1073/pnas.0809737105

\section{Figures}

\section{$\beta$-Carotene}
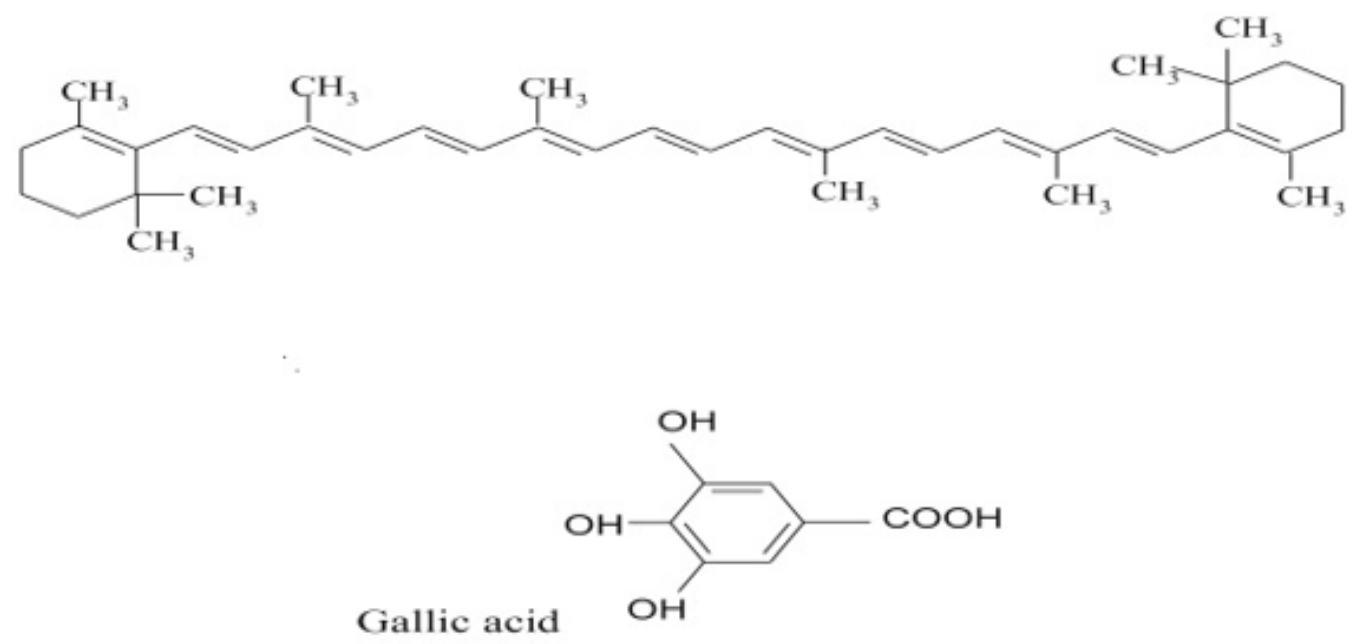

Page $11 / 16$ 
Figure 1

Chemical structures of $\beta$-carotene and gallic acid

A

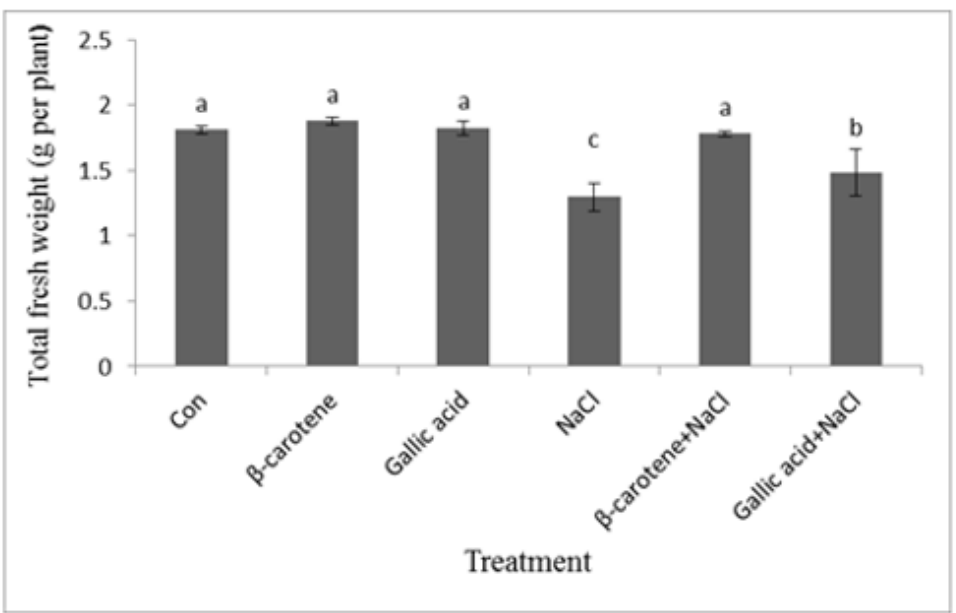

B

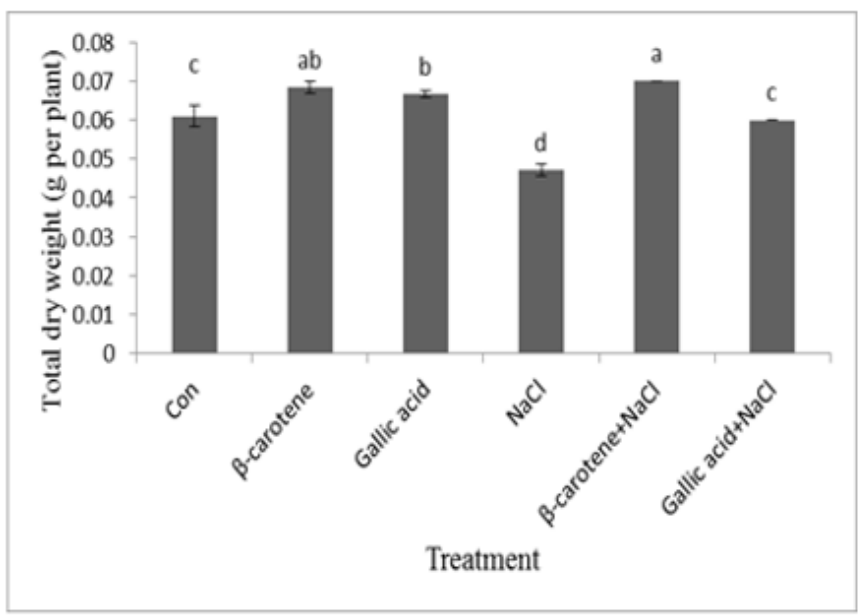

Figure 2

Effect of $\beta$-carotene and gallic acid, sodium chloride, $\beta$-carotene + sodium chloride and gallic acid + sodium chloride on the total fresh weight (A) and the total dry weight (B) in Lepidium sativum seedlings (different letters indicate a significant difference between the means at the level of 0.05 with the Duncan test).

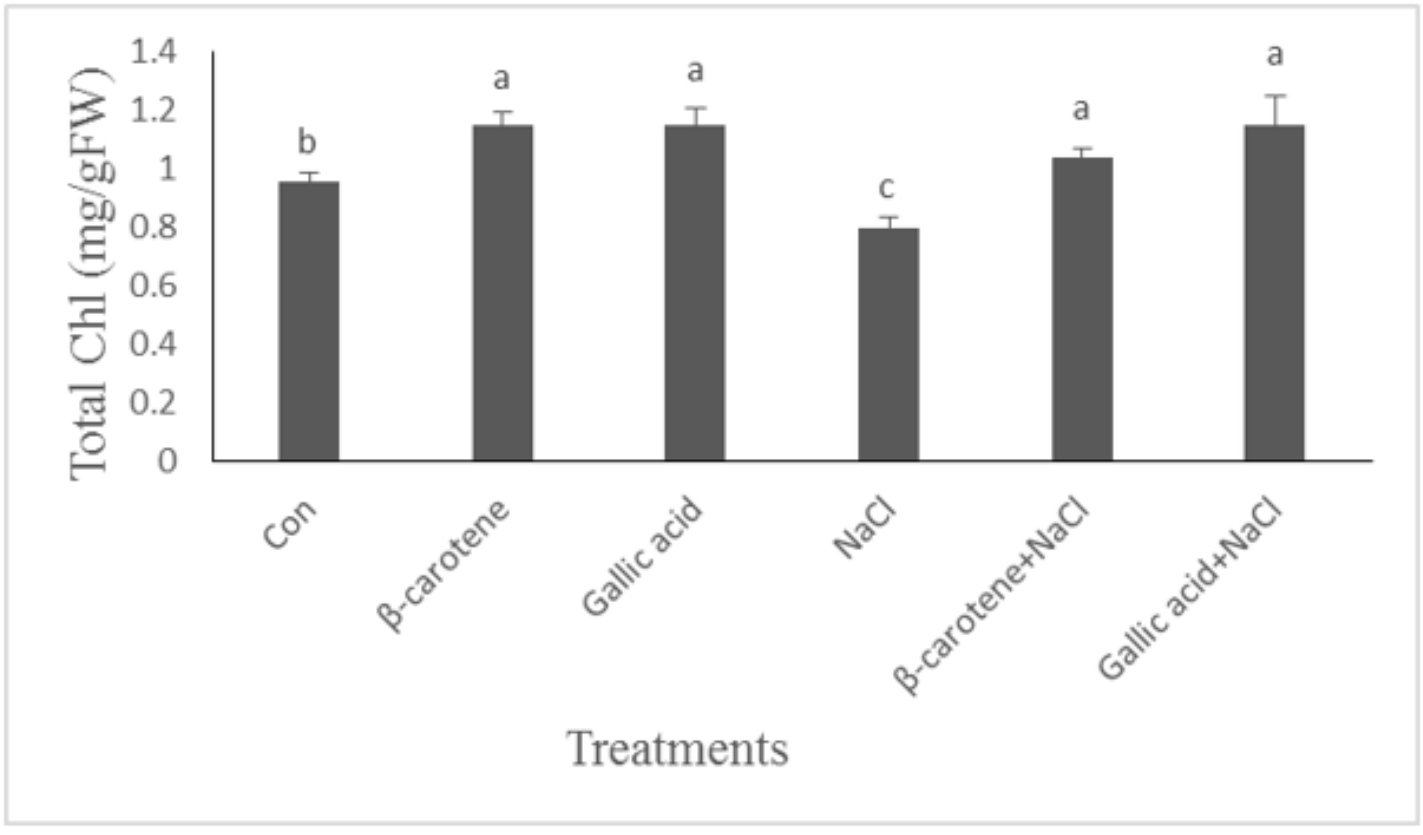

\section{Figure 3}

Effect of $\beta$-carotene and gallic acid, sodium chloride, $\beta$-carotene + sodium chloride, and gallic acid + sodium chloride on the total chlorophyll content in Lepidium sativum seedlings (different letters indicate a significant difference between the means at the level of 0.05 with Duncan test). 
A

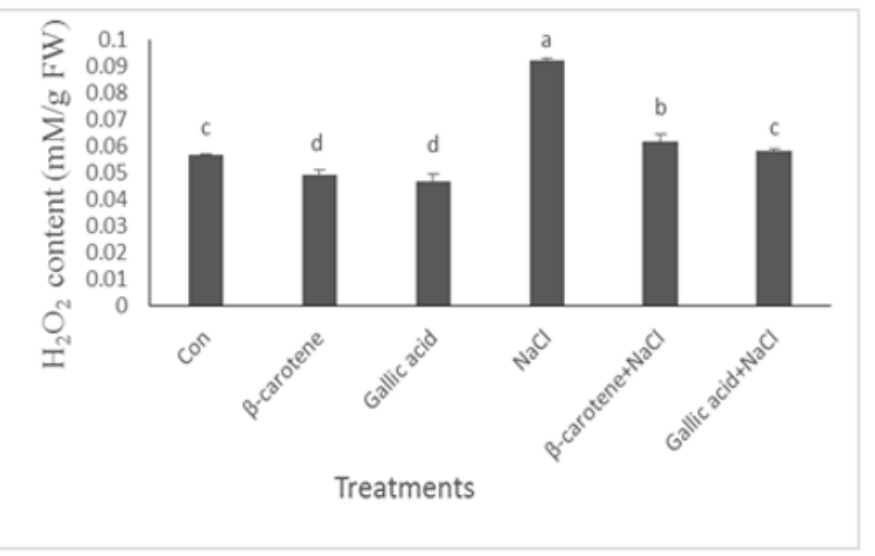

B

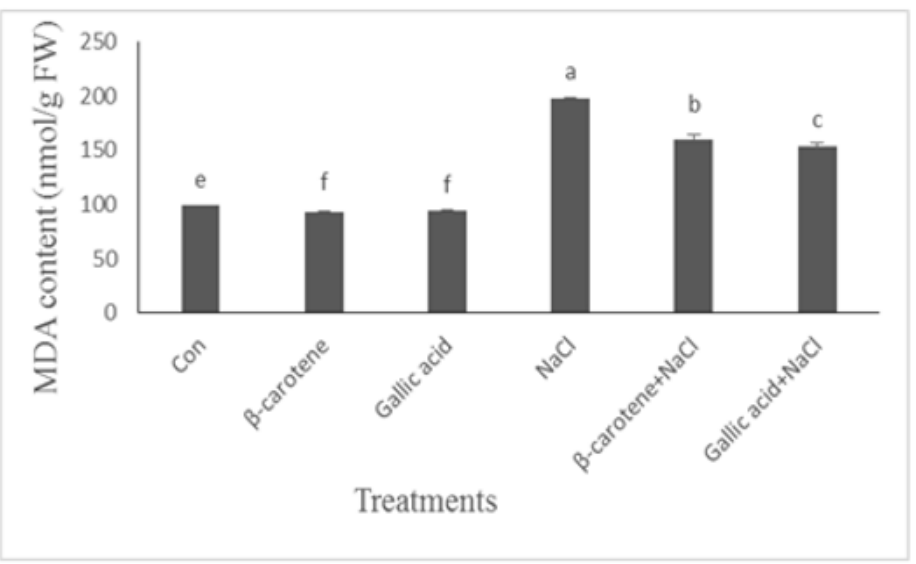

\section{Figure 4}

Effect of $\beta$-carotene and gallic acid, sodium chloride, $\beta$-carotene + sodium chloride and gallic acid + sodium chloride on $\mathrm{H}_{2} \mathrm{O}_{2}$ content (A) and MDA content (B) in Lepidium sativum seedlings (different letters indicate a significant difference between the means at the level of 0.05 with Duncan test).

A

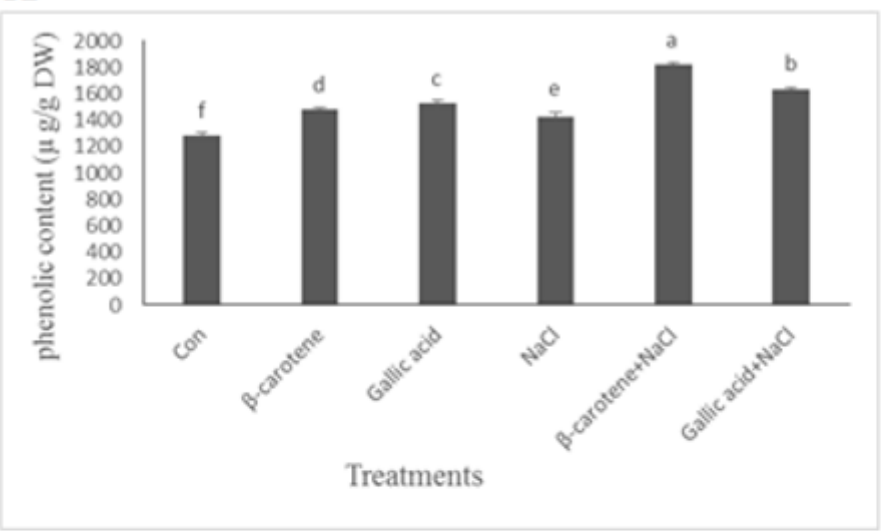

$\mathrm{B}$

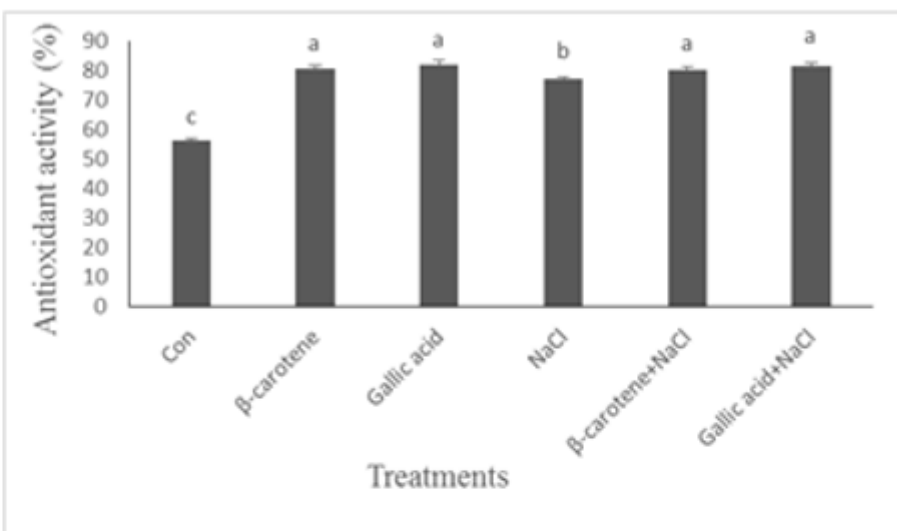

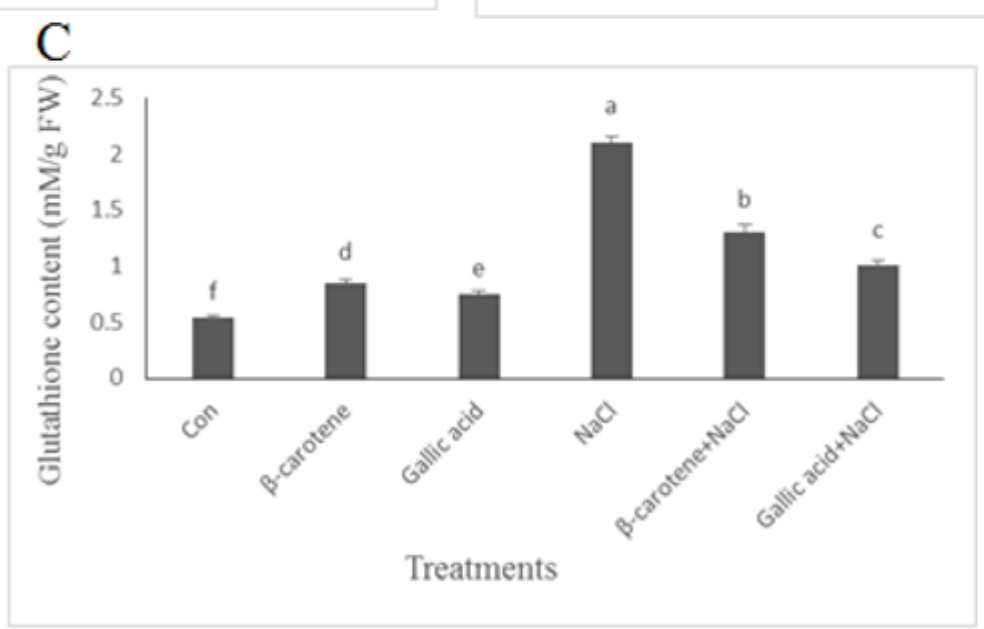

Figure 5 
Effect of $\beta$-carotene and gallic acid, sodium chloride, $\beta$-carotene + sodium chloride and gallic acid + sodium chloride on the phenolic content (A), glutathione content (B), and DPPH radical scavenging activity (C) in Lepidium sativum seedlings (different letters indicate a significant difference between the means at the level of 0.05 with Duncan test).

A

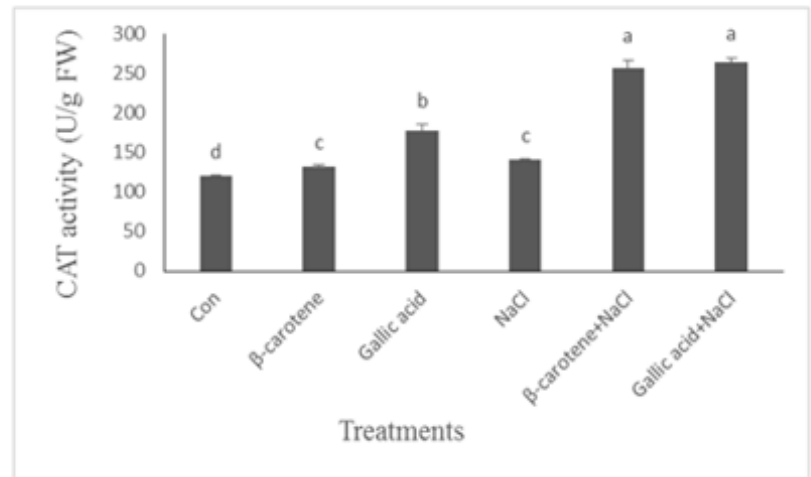

C

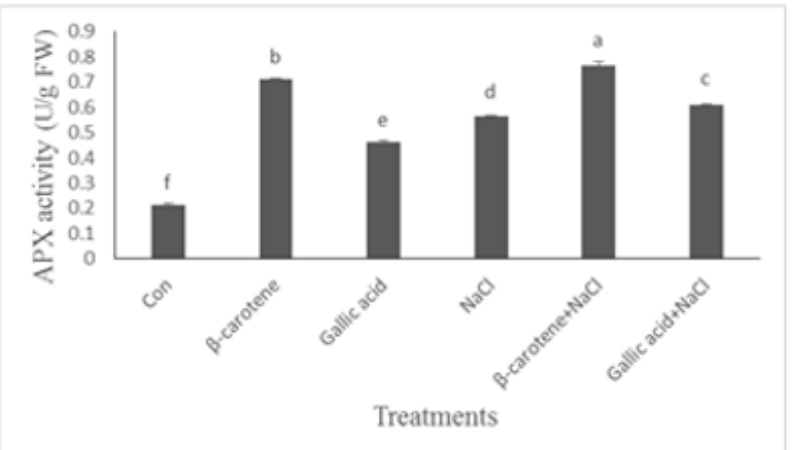

$\mathrm{B}$

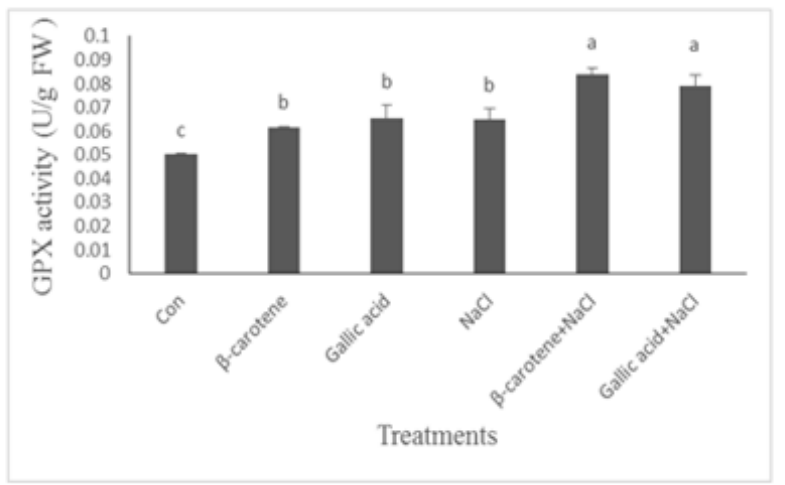

D

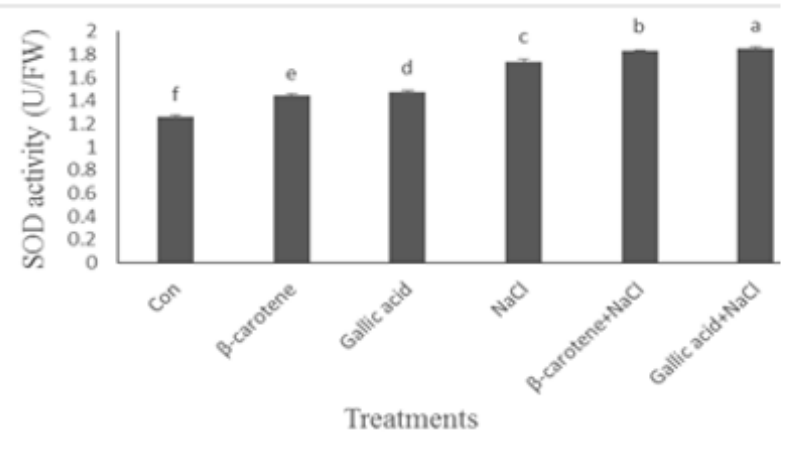

$\mathrm{E}$

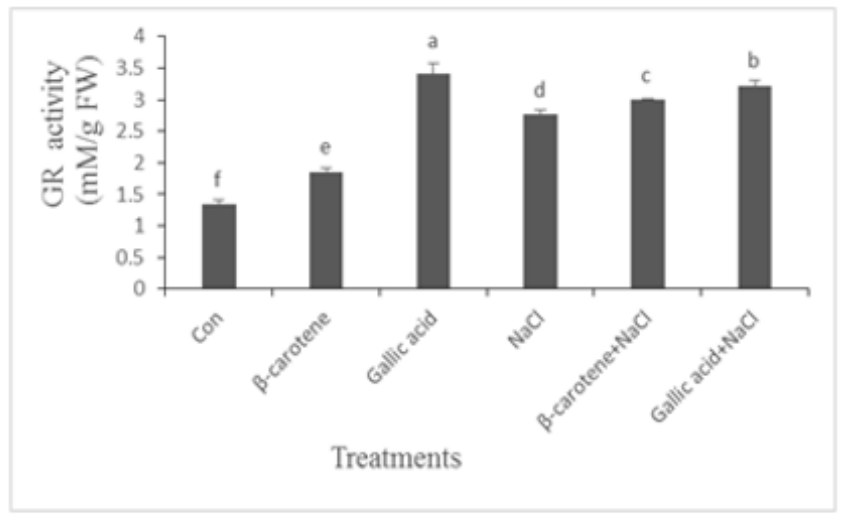

Figure 6

Effect of $\beta$-carotene and gallic acid, sodium chloride, beta-carotene + sodium chloride and gallic acid + sodium chloride on CAT (A), GPX (B) and APX (C), SOD (D), GR (E) enzyme activities in Lepidium sativum seedlings (different letters indicate a significant difference between the means at the level of 0.05 with Duncan test). 
A

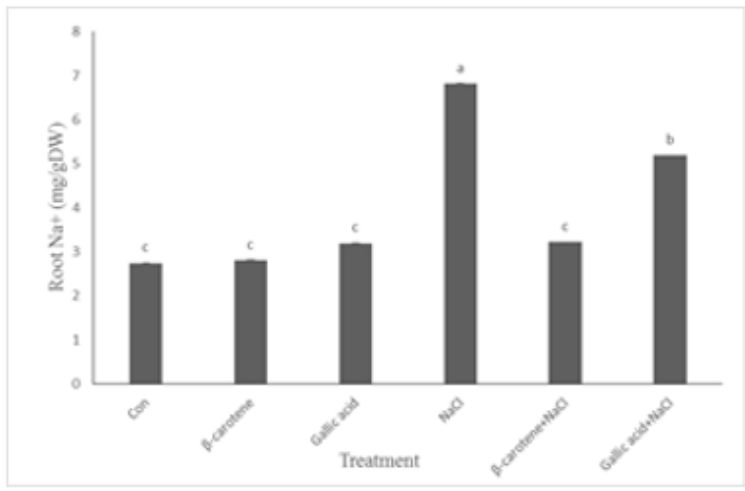

C

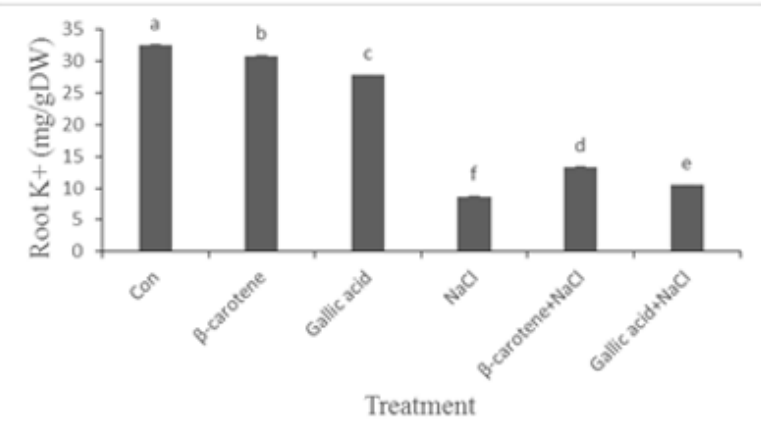

$\mathbf{E}$

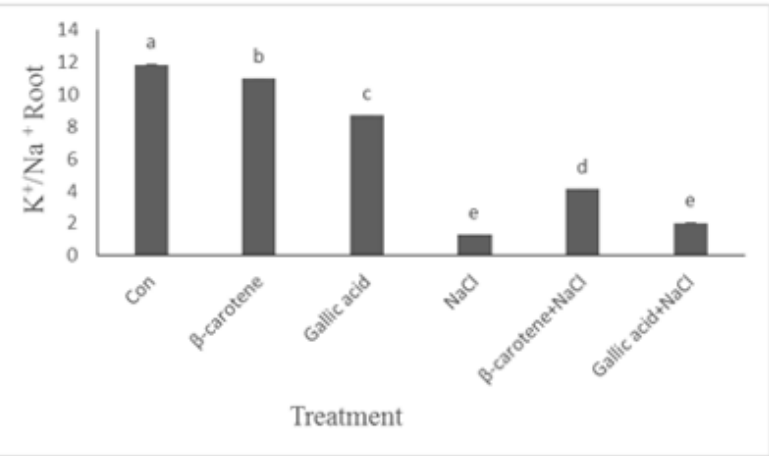

B

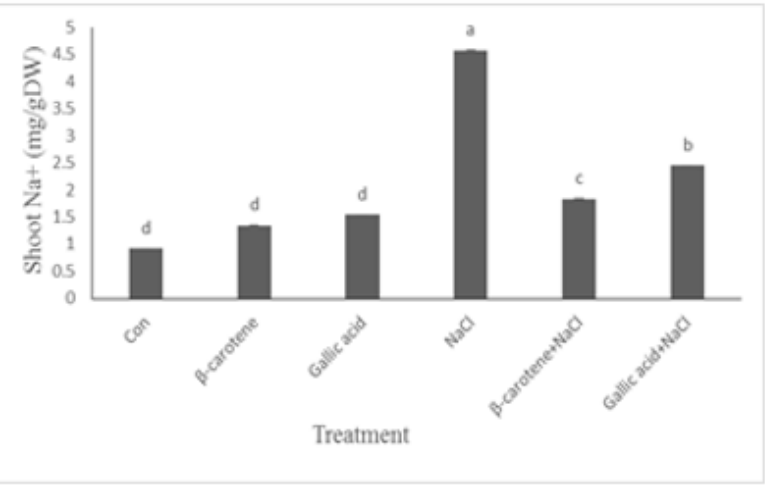

D

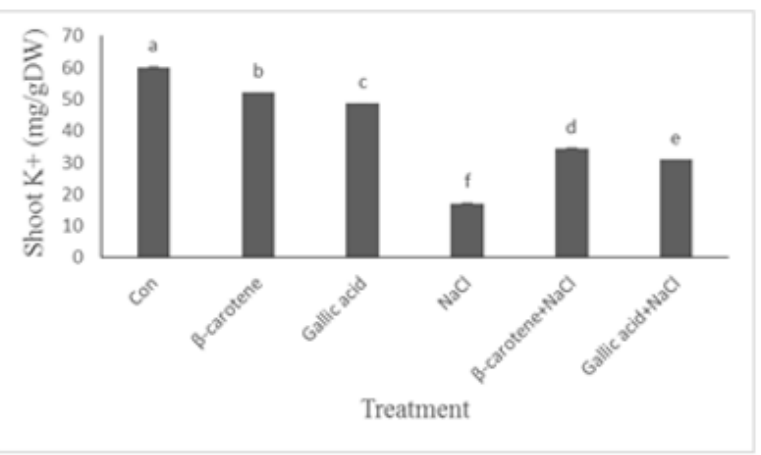

$\mathbf{F}$

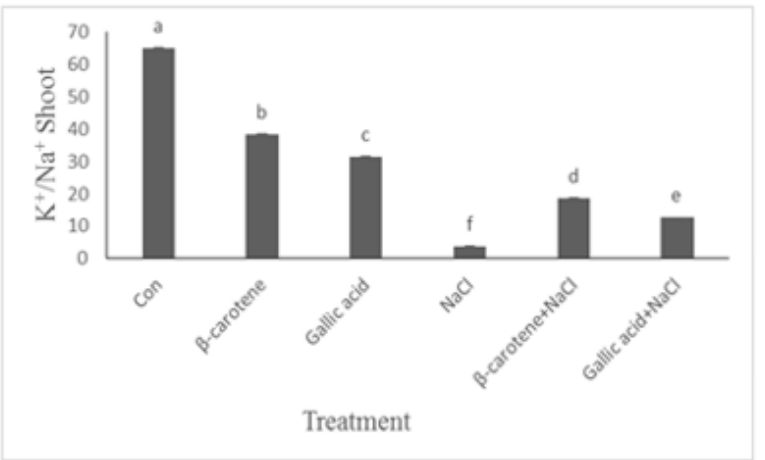

\section{Figure 7}

Effect of $\beta$-carotene and gallic acid, sodium chloride, $\beta$-carotene + sodium chloride and gallic acid + sodium chloride on $\mathrm{Na}^{+}$of root (A), $\mathrm{Na}^{+}$of shoot (B), $\mathrm{K}^{+}$of root (C), $\mathrm{K}^{+}$of shoot (D), $\mathrm{K}^{+} / \mathrm{Na}^{+}$ratio of roots $(\mathrm{E}), \mathrm{K}^{+} / \mathrm{Na}^{+}$ratio of shoot (G) in Lepidium sativum seedlings (different letters indicate a significant difference between the means at the level of 0.05 with Duncan test). 


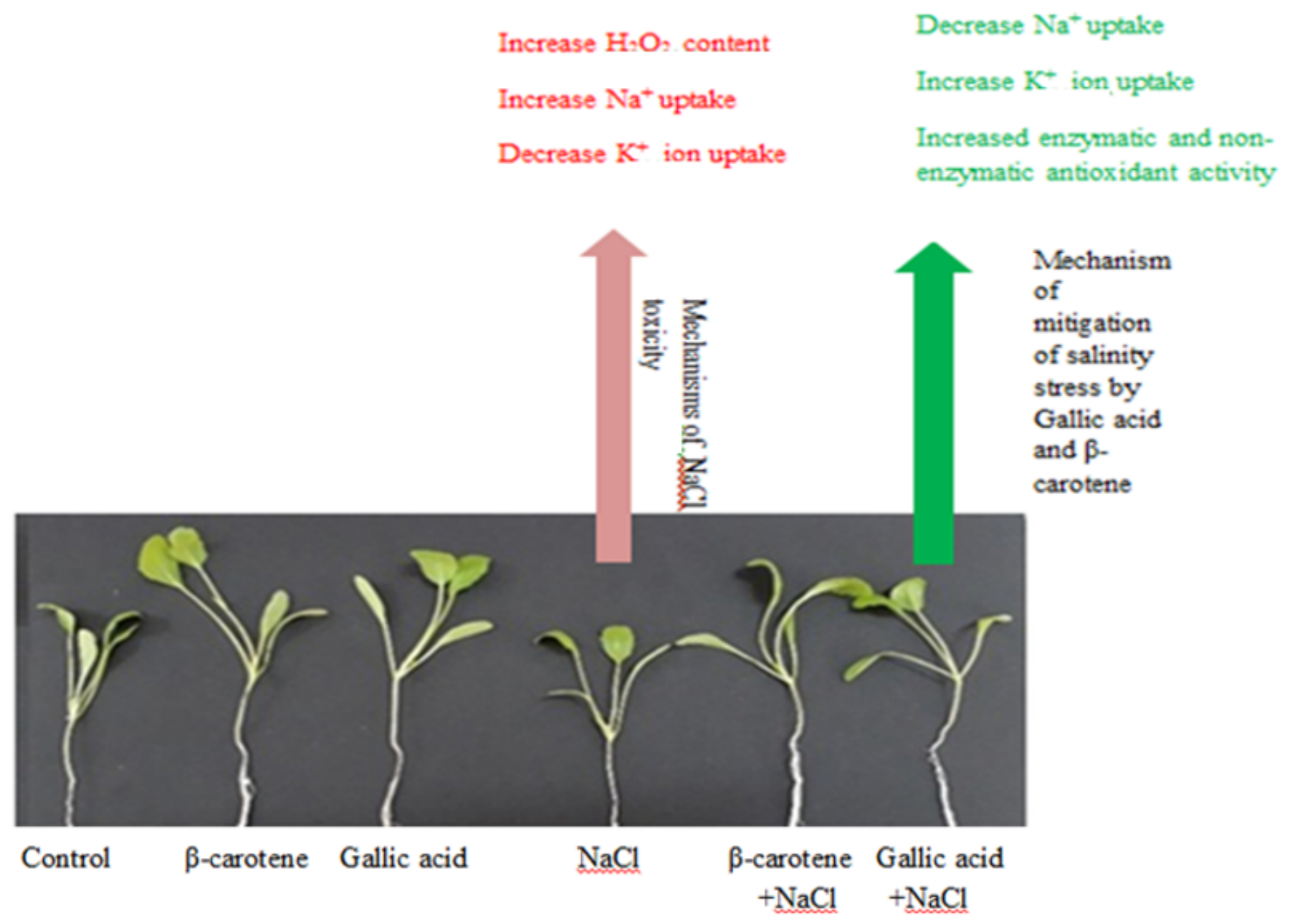

Figure 8

A schematic image showing the $\mathrm{NaCl}$ toxicity \& mitigation mechanisms of $\mathrm{NaCl}$ toxicity by $\beta$-carotene \& gallic acid in Lepidium sativum

\section{Supplementary Files}

This is a list of supplementary files associated with this preprint. Click to download.

- FigureSuppl.docx 